\title{
Study of Fluctuations in the Groundwater Level in Rajasthan: A Spatio-Temporal Approach
}

\author{
Parimita Saikia \\ Department of Geography, \\ The Assam Royal Global University \\ Guwahati, India
}

\author{
Dr. Narayan Chetry \\ Department of Geography, \\ The Assam Royal Global University \\ Guwahati, India
}

\begin{abstract}
Groundwater is a major source of freshwater in many parts of the world. Some regions are excessively dependent on it leading to groundwater consumption faster than it can be naturally replenished and causing water tables to decline unremittingly. Rajasthan is the largest state in the country and water resources supporting the human population are very less. Rajasthan has its water problems more-over, it is undergoing an industrial transformation. The objective of this study is to identify the groundwater critical zones, study the fluctuation of groundwater level and analyse the trend of groundwater level for each district using the Man-Kendall Test. In this study, Inverse Distance Weightage was applied for estimating the attribute values of locations that are within the database using known data values. Then the interpolated data values were extracted for Statistical Analysis using Man-Kendall's Test. Despite its importance, groundwater is poorly understood and often undervalued. Despite its importance, groundwater is poorly understood and often underestimated. Results show that the groundwater level had been at the most critical in 2010, i.e. $-\mathbf{1 1 9} \mathrm{m}$ bgl in pre-monsoon and $112 \mathrm{~m}$ bgl in post Monsoon. From 1996 to 2016, Mann-Kandell's Trend test illustrated a declining trend in Alwar, Dausa, Jaipur, Jaisalmer, Jhunjhunun, Sawai Madhopur and Sikar districts of Rajasthan.
\end{abstract}

Keywords- Groundwater level, Inverse Distance Weightage interpolation, Mann-Kendall trend analysis

\section{INTRODUCTION}

Groundwater accounts for about 20 percent of the world's fresh water. But still less than 1 percent of all the water on Earth, comprising all ocean water and permanent ice. Groundwater refers to the water found beneath the Earth's surface. This water originates mostly from rain, melted snow, and other water that seeps through soil, or the cracks in the rocks. Due to gravity, the water moves downward, below the Earth's surface, until it hits a layer of rock or it can't get through, where it remains there and builds up. This section of water below the surface is called an aquifer. Groundwater can eventually go back up to the surface in the form of springs and wetlands (Chinnasamy et al., 2015).

In various places, groundwater discharged naturally into natural springs or contributed to rivers and wetlands. During droughts, groundwater often plays a vital role in sustaining rivers and streams and becomes a valuable buffer. Groundwater is a finite resource, and aquifers can become depleted when extraction rates exceed replenishment, or 'recharge', rates. Like surface water, groundwater can become polluted or contaminated (National Centre for Groundwater Research and Training).

The objectives of this study are to find the groundwater critical zones in Rajasthan, identify the seasonal variation of groundwater level and the trend of groundwater level and fluctuation.

Rajasthan is a state with low to extremely low rainfall, intense summers with very high temperatures, high diurnal variation of temperatures and low humidity and high evaporation. It is one such Indian state with complex agro-climatic zones and in urgent need of expanding groundwater resources. Moreover, increase in population and urbanization leads to groundwater depletion. Thus, groundwater study plays an important role in assessment, monitoring, planning, development and Integrated Water Resources Management in Rajasthan [1].

\section{MATERIALS AND METHODS}

\section{A. Study area}

The present study focuses on water resources of Rajasthan and its districts. Rajasthan is the largest State in the country with total geographical area of $342,239 \mathrm{~km}^{2}$ and comprises of 33 districts (Yadav et al., 2016). According to 2011 census, it has a total population of $68,548,437$. The state accounts for more than $10 \%$ of India's geographical area, supports about $5 \%$ of the human population and $20 \%$ of the livestock but only possesses $1.2 \%$ of the total surface water and $1.7 \%$ of the groundwater available in India. The Aravalli hill ranges, running from north east to south-west, divide the state approximately into the western arid and eastern semi-arid regions. Rajasthan's economy has undergone considerable transformation in the recent past, with agriculture (including livestock) providing one-fourth of the state's GDP. Approximately 5.4 million households are engaged in farming, while $60 \%$ of the state's population depend on agriculture for their livelihood. Rajasthan is heavily dependent on groundwater for irrigation and about $90 \%$ of the drinking water and $60 \%$ of the irrigation water is sourced from groundwater supplies. The pressure on groundwater is further growing due to population growth and an increased number of industries. About $80 \%$ of the State areas have witnessed groundwater depletion and many towns and villages have experienced a shortage of drinking water, particularly in summer months (Chinnasamy et al., 2015). 


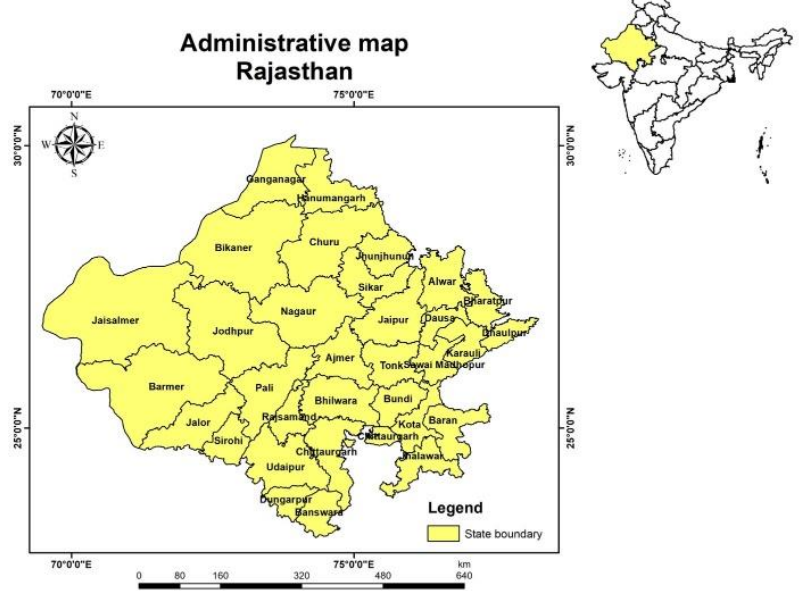

Fig.1: Location map of Rajasthan

\section{B. Methodology}

Data was obtained from India-WRIS WebGIS (http://cgwb.gov.in/GW-data-access.html) which is a joint project of the Central Water Commission (CWC), Ministry of Water Resources, Govt. of India and Indian Space Research Organization (ISRO), Department of Space, Govt. of India to create a spatial database in MS-Excel for the years 1996 to 2015 (CGWB).

Secondly, data was imported in ArcGIS software and Inverse Distance Weightage (IDW) was applied for estimating the attribute values of locations that are within the range of available data using known data values. The area of Rajasthan was clipped from the interpolated data using Model Builder. These values were extracted to MS-Excel for statistical analysis. The missing data were calculated using the preceding and succeeding data using the following formula:

$$
a+\frac{(b-a)}{3}
$$

where, $a=$ preceding year data value, $b=$ succeeding year data value

The Mann-Kendall (MK) test is a non-parametric method for identifying trends in time-series data. The Mann-Kendall test checks the null hypothesis of no trend versus the alternative hypothesis of the existence of increasing or decreasing trend (Narjary et al., 2014). In XLSTAT, using Trend Analysis tool, Man-Kendall's Test was carried out for the interpolated data.

Each data value is compared to all subsequent data values. The initial value of the MK statistic, $\tau$ (tau), is assumed to be 0 (i.e. no trend). If a data value at a later time is higher than a data value of an earlier time, $\tau$ is incremented by 1 . On the other hand, if the data value at a later time is lower than a data value sampled earlier, $\tau$ is decremented by 1 . The net result of all such increments and decrements yields the final value of $\tau$.

Let $x_{1}, x_{2}, \ldots, x_{n}$ represent $n$ data points, where $x_{j}$ represents the data point at time $j$. Then, the MK $(\tau)$ is given by

$$
\tau=\sum_{k-1}^{n-1} \sum_{j=k+1}^{n} \operatorname{sign}\left(x_{j}-x_{k}\right)
$$

where, $\operatorname{sign}\left(x_{j}-x_{k}\right)=1$ if $\left(x_{j}-x_{k}\right)>0$,

$$
=0 \text { if }\left(x_{j}-x_{k}\right)=0 \text {, }
$$$$
=-1 \text { if }\left(x_{j}-x_{k}\right)<0 \text {. }
$$

A high positive value of $\tau$ is an indicator of an increasing trend, and a low negative value indicates a decreasing trend. Sen's slope estimator provides an estimate of the magnitude of the detected trend and is calculated as

$$
T_{i}=\frac{\left(x_{j}-x_{k}\right)}{j-k} \quad \text { for } i=1,2 \ldots . N,
$$

where $x_{i}$ and $x_{j}$ are data values at time $j$ and $k(j>k)$ respectively. The median of ( $\beta) N$ values of $T_{i}$ is the Sen's slope estimator.

$$
\begin{aligned}
& \beta=T_{((N+1) / 2)}, \text { if } N \text { is odd } \\
& \beta=\frac{1}{2}\left(T_{N / 2}+T_{(N+2) / 2}\right), \text { if } N \text { is even }
\end{aligned}
$$

Positive value of $\beta$ indicates an increasing trend, and negative value indicates a decreasing trend in the time series (Narjary et al., 2014). Overall methodology adopted in the study is shown in Fig. 2.

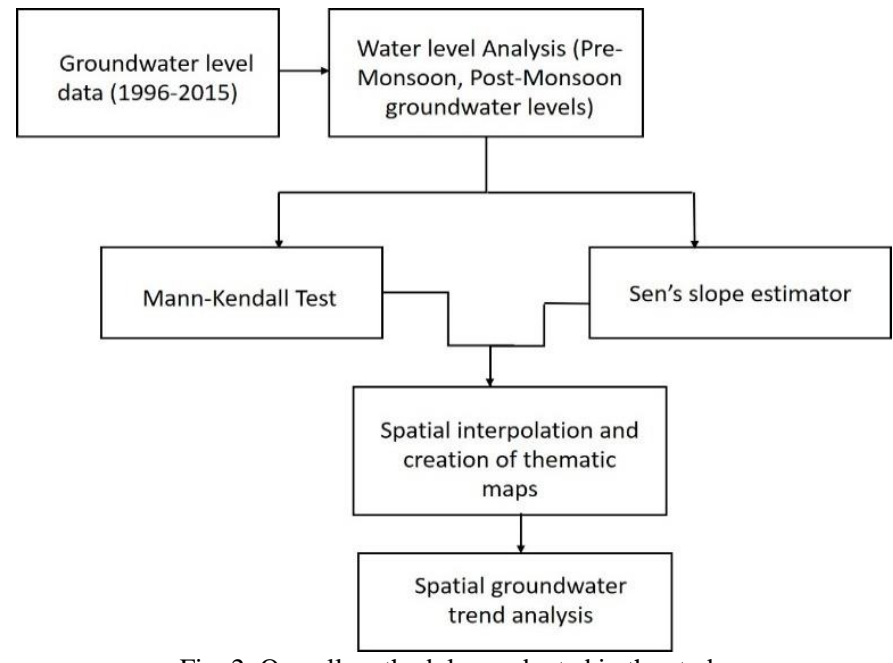

Fig. 2: Overall methodology adopted in the study

\section{RESULTS AND DISCUSSIONS}

There is a dynamic balance of water levels in aquifers between ground-water recharge, storage, and discharge. If recharge exceeds discharge, the volume of water in storage will increase and water levels will rise; if discharge exceeds recharge, the volume of water in storage will decrease and water levels will fall. It is because recharge and discharge are not distributed uniformly in space and time, ground-water levels are continuously rising or falling to adjust to the resulting imbalances (Rede, 2012). Figure 2 to Figure 6 illustrates variations groundwater levels for years 1996, 2000, 2005, 2010 and 2015 has been shown for pre-monsoon and post-monsoon seasons.

A. Spatial variation of groundwater level in Rajasthan

It can be proposed from the Fig. 3, in the year 1996, the groundwater level in post-monsoon was as low as $104.64 \mathrm{~m} \mathrm{bgl}$ and as high as $-1.01 \mathrm{~m}$ bgl. In the year 2000, the groundwater level in post-monsoon was as low as $110.71 \mathrm{~m} \mathrm{bgl}$ and as high as $-1.20 \mathrm{~m} \mathrm{bgl}$ as shown in Fig. 4. It can be proposed from Fig. 5 that in 2005, the groundwater level in pre-monsoon was as low as $110.97 \mathrm{~m} \mathrm{bgl}$ and as high as $-3.34 \mathrm{~m} \mathrm{bgl}$. Fig. 6 proposed that in the year 2010 the groundwater levels in post-monsoon was as low as $119.99 \mathrm{~m} \mathrm{bgl}$ and as high as $-1.05 \mathrm{~m} \mathrm{bgl}$. We also found the critical zones have increased in the pre-monsoon. But in post-monsoon the groundwater level increased by $-7.44 \mathrm{~m}$ $\mathrm{bgl}$ and maximum groundwater level increased to $-0.26 \mathrm{~m} \mathrm{bgl}$. In Fig. 7, the variation of groundwater level in 2015 seems to be more in the pre-monsoon season and the depth is as low as $118.24 \mathrm{~m} \mathrm{bgl}$ and in the post-monsoon season, it is $110.50 \mathrm{~m}$ bgl. It can be seen in the figure that the groundwater levels in post-monsoon was as low as $-118.24 \mathrm{~m} \mathrm{bgl}$ and as high as -0.21 m bgl. 


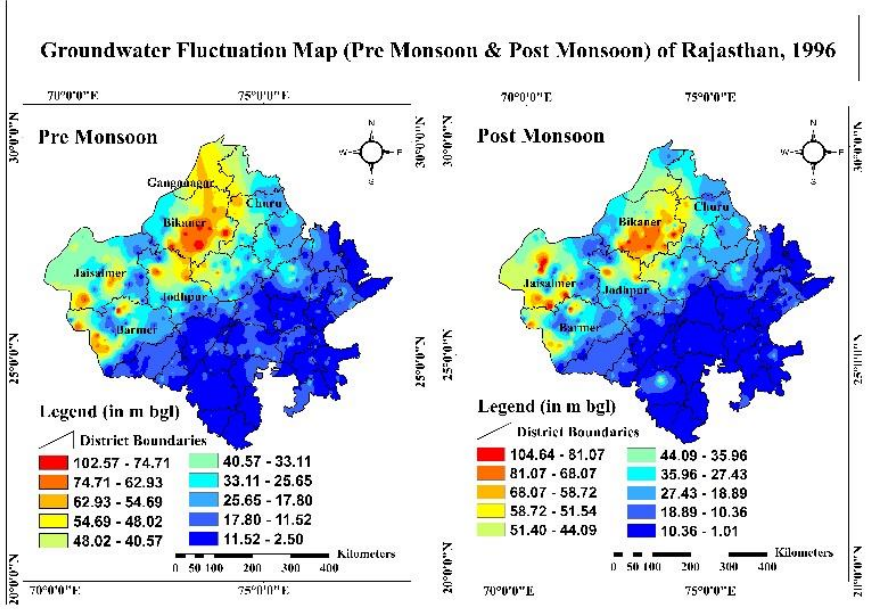

Fig. 3: Groundwater level fluctuation map, 1996

Groundwater Fluctuation Map (Pre Monsoon \& Post Monsoon) of Rajasthan, 2000

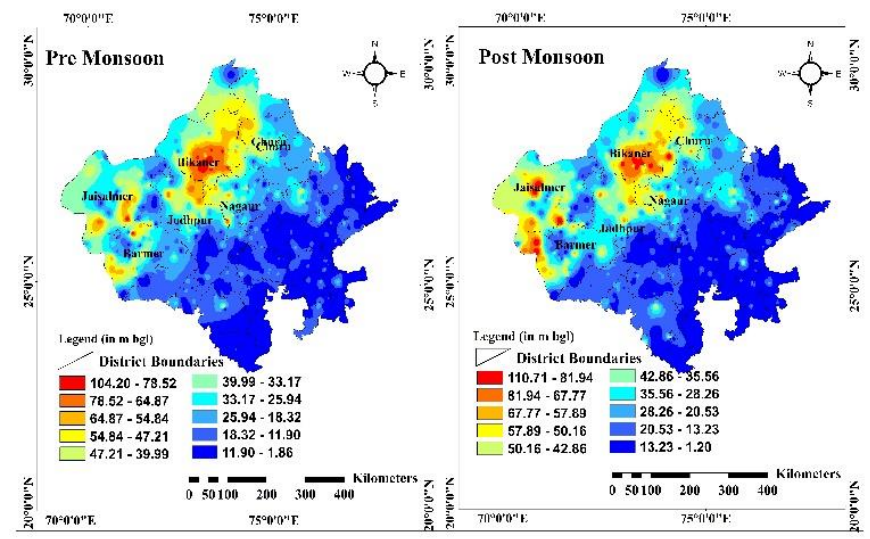

Fig. 4: Groundwater level fluctuation map, 2000

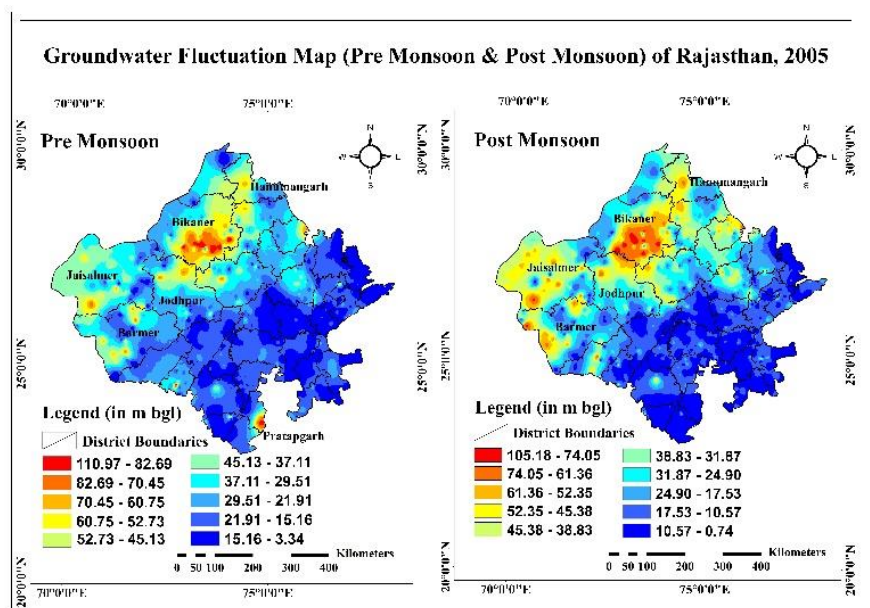

Fig. 5 Groundwater level fluctuation map, 2005

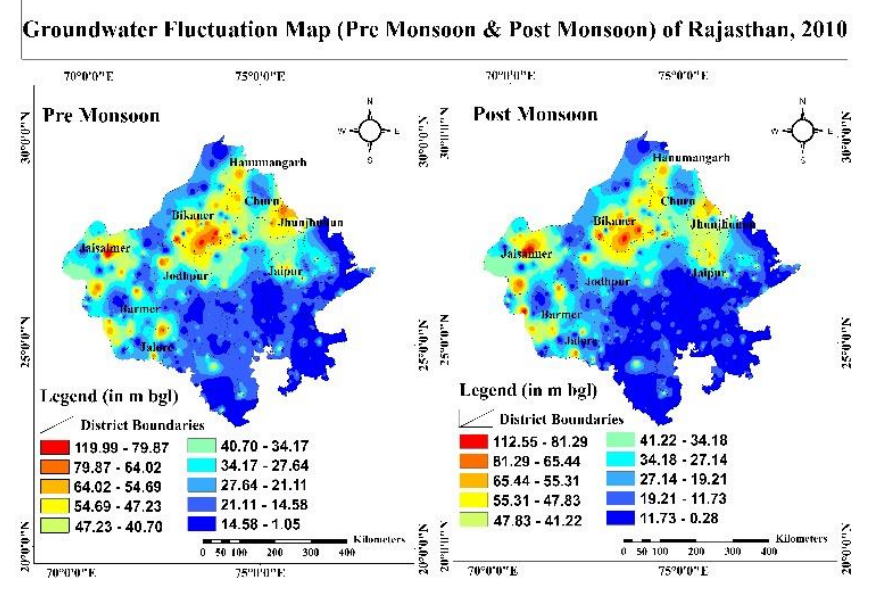

Fig. 6: Groundwater level fluctuation map, 2010

Groundwater Fluctuation Map (Pre Monsoon \& Post Monsoon) of Rajasthan, 2015

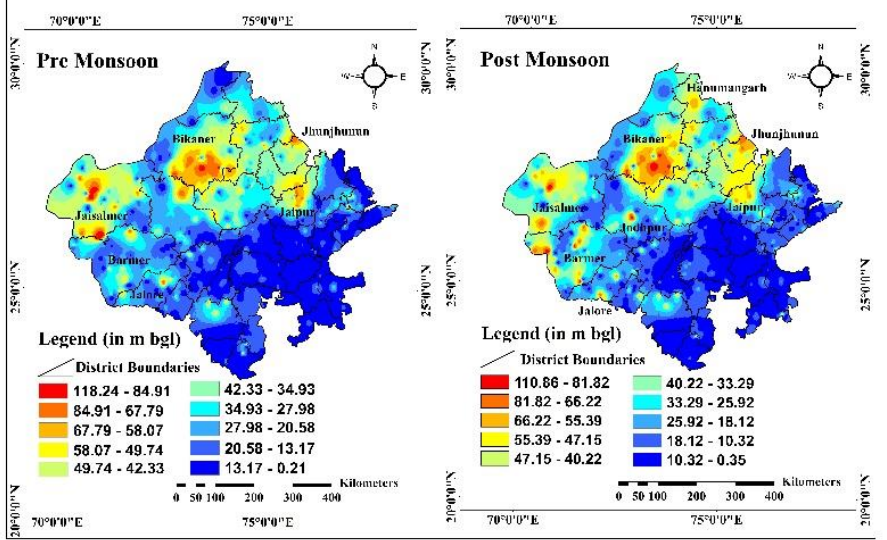

Fig. 7: Groundwater level fluctuation map, 2015 
B. Trend of groundwater levels during using MannKendall and Sen's slope methods (Pre-monsoon season)

Table 1 Trends in groundwater levels at different districts during pre-monsoon season

\begin{tabular}{|l|l|l|l|l|}
\hline \multirow{2}{*}{ Districts } & \multicolumn{2}{|l|}{ Pre-monsoon (Min) } & \multicolumn{2}{l|}{ Pre-monsoon (Max) } \\
\cline { 2 - 5 } & $\begin{array}{l}\text { Kendall } \\
\text { s } \text { tau }\end{array}$ & $\begin{array}{l}\text { Sen's } \\
\text { slope }\end{array}$ & $\begin{array}{l}\text { Kendall's } \\
\text { tau }\end{array}$ & $\begin{array}{l}\text { Sen's } \\
\text { slope }\end{array}$ \\
\hline Ajmer & -0.0212 & -0.0096 & 0.2540 & 0.1283 \\
\hline Alwar & -0.3598 & -1.1241 & -0.1587 & -0.0413 \\
\hline Banswara & -0.6561 & -2.6907 & 0.4339 & 0.3355 \\
\hline Baran & 0.0952 & 0.0524 & 0.5185 & 0.0587 \\
\hline Barmer & 0.0212 & 0.0170 & -0.2963 & -0.0807 \\
\hline Bharatpur & -0.5119 & -1.7022 & 0.2691 & 0.0926 \\
\hline Bhilwara & 0.1058 & 0.1468 & 0.2751 & 0.0434 \\
\hline Bikaner & -0.2646 & -0.3537 & 0.4127 & 0.2561 \\
\hline Bundi & 0.5291 & 0.7792 & -0.0529 & -0.0087 \\
\hline Chittaurgarh & -0.1905 & -0.3746 & 0.3598 & 0.2044 \\
\hline Churu & -0.9524 & -2.1962 & 0.2434 & 0.1656 \\
\hline Dausa & -0.6243 & -1.6487 & -0.3810 & -0.1634 \\
\hline Dhaulpur & -0.5013 & -1.0094 & 0.1214 & 0.0334 \\
\hline Dungarpur & 0.0317 & 0.1114 & 0.2116 & 0.1151 \\
\hline Ganganagar & -0.3386 & -0.6024 & 0.5714 & 0.4248 \\
\hline Hanumangarh & -0.3386 & -0.6024 & 0.5714 & 0.4248 \\
\hline Jaipur & -0.5503 & -1.8960 & -0.1693 & -0.0881 \\
\hline Jaisalmer & -0.5714 & -1.7214 & -0.4550 & -0.1008 \\
\hline Jalore & -0.5079 & -2.5950 & 0.2222 & 0.1444 \\
\hline Jhalawar & 0.5185 & 0.3163 & 0.2646 & 0.1152 \\
\hline Jhunjhunun & -0.6032 & -2.4405 & -0.4656 & -1.1831 \\
\hline Jodhpur & -0.0423 & -0.0557 & 0.3386 & 0.1730 \\
\hline Karauli & -0.0741 & -0.0366 & 0.4908 & 0.2307 \\
\hline Kota & 0.0423 & 0.0159 & 0.4339 & 0.1029 \\
\hline Nagaur & -0.2646 & -0.3922 & -0.0952 & -0.0593 \\
\hline Pali & -0.0741 & -0.4625 & 0.2963 & 0.0620 \\
\hline Pratapgarh & -0.2540 & -0.6612 & -0.2434 & -0.1677 \\
\hline Rajsamand & -0.3704 & -0.3383 & -0.3280 & -0.0838 \\
\hline $\begin{array}{l}\text { Sawai } \\
\text { Madhopur }\end{array}$ & -0.2963 & -0.7684 & -0.2434 & -0.0492 \\
\hline Sikar & -0.6243 & -0.9756 & -0.6667 & -1.0707 \\
\hline Sirohi & -0.2116 & -0.8049 & 0.2857 & 0.1852 \\
\hline Tonk & -0.1164 & -0.2195 & 0.3598 & 0.0857 \\
\hline Udaipur & -0.2011 & -0.3043 & 0.0317 & 0.0032 \\
\hline Note: (Min $)$ stand & & \\
\hline
\end{tabular}

Note: (Min.) stands for minimum groundwater level; (Max.) stands for maximum groundwater level
C. Trend of groundwater levels during using Mann- Kendall and Sen's slope methods (Post-monsoon)

D.

Table 2 Trends in groundwater levels at different districts during post-monsoon season

\begin{tabular}{|l|l|l|l|l|}
\hline \multirow{2}{*}{ Districts } & Post-monsoon (Min) & \multicolumn{2}{l|}{ Post-monsoon (Max) } \\
\cline { 2 - 5 } & $\begin{array}{l}\text { Kendall's } \\
\text { tau }\end{array}$ & $\begin{array}{l}\text { Sen's } \\
\text { slope }\end{array}$ & $\begin{array}{l}\text { Kendall' } \\
\text { s tau }\end{array}$ & $\begin{array}{l}\text { Sen's } \\
\text { slope }\end{array}$ \\
\hline Ajmer & 0.2269 & 0.5086 & 0.3325 & 0.1346 \\
\hline Alwar & -0.4486 & -0.9758 & -0.0792 & -0.0038 \\
\hline Banswara & -0.5714 & -3.1997 & -0.4127 & -0.2017 \\
\hline Baran & 0.3958 & 1.0316 & 0.2164 & 0.0392 \\
\hline Barmer & 0.0264 & 0.0847 & 0.3113 & 0.1815 \\
\hline Bharatpur & 0.3958 & 0.1370 & -0.5435 & -0.3209 \\
\hline Bhilwara & -0.2480 & -0.4253 & 0.4274 & 0.0841 \\
\hline Bikaner & -0.1636 & -0.1703 & 0.4169 & 0.3048 \\
\hline Bundi & 0.6174 & 0.9038 & 0.3536 & 0.0735 \\
\hline Chittaurgarh & -0.3430 & -0.6221 & 0.4697 & 0.2292 \\
\hline Churu & -0.9129 & -1.8722 & 0.1953 & 0.1290 \\
\hline Dausa & -0.6280 & -1.4821 & -0.2269 & -0.1998 \\
\hline Dhaulpur & -0.7335 & -1.2920 & 0.3958 & 0.2193 \\
\hline Dungarpur & 0.3852 & 1.8065 & 0.4063 & 0.1164 \\
\hline Ganganagar & -0.3641 & -0.6185 & 0.4274 & 0.4667 \\
\hline $\begin{array}{l}\text { Hanumanga } \\
\text { rh }\end{array}$ & -0.3641 & -0.6185 & 0.4274 & 0.4667 \\
\hline Jaipur & -0.5435 & -1.3479 & -0.0369 & -0.0237 \\
\hline Jaisalmer & -0.2480 & -0.5591 & -0.2269 & -0.0734 \\
\hline Jalore & -0.5963 & -2.7926 & 0.5858 & 0.3269 \\
\hline Jhalawar & -0.2586 & -0.1977 & 0.2586 & 0.0706 \\
\hline Jhunjhunun & -0.6174 & -2.7668 & -0.3641 & -0.6442 \\
\hline Jodhpur & -0.1319 & -0.2389 & 0.5435 & 0.1817 \\
\hline Karauli & 0.0053 & 0.0214 & 0.5963 & 0.1662 \\
\hline Kota & 0.1319 & 0.0760 & 0.4802 & 0.0899 \\
\hline Nagaur & -0.2164 & -0.2790 & 0.2058 & 0.1731 \\
\hline Pali & 0.3219 & 0.7122 & 0.4591 & 0.0970 \\
\hline Pratapgarh & -0.3430 & -0.7622 & 0.2269 & 0.1644 \\
\hline Rajsamand & -0.1636 & -0.1841 & 0.2691 & 0.0405 \\
\hline $\begin{array}{l}\text { Sawai } \\
\text { Madhopur }\end{array}$ & -0.5013 & -1.2581 & -0.0053 & -0.0042 \\
\hline Sikar & -0.5752 & -0.9235 & -0.7757 & -0.8206 \\
\hline Sirohi & -0.3958 & -1.1890 & 0.3430 & 0.1768 \\
\hline Tonk & 0.1953 & 0.5125 & 0.5541 & 0.1390 \\
\hline Udaipur & 0.1847 & 0.0519 & 0.4486 & 0.1407 \\
\hline & & & &
\end{tabular}

Note: (Min.) stands for minimum groundwater level; (Max.) stands for maximum groundwater level

The statistical techniques of Mann-Kendall (MK) test and Sen's slope estimator were applied to understand the trend of groundwater level of the study area during the study period on a temporal scale and also to forecast the future groundwater scenario. Each of the sampled groundwater fluctuation of the neighbouring areas. Thus, the trend value reflects the overall groundwater fluctuation (Biswas et al., 2018). Table 1 and 2 shows the trends in groundwater levels at different districts during pre-monsoon and post monsoon. It can been observed from the tables that pre-monsoon (min) groundwater level in Ajmer, Alwar, Banswara, Bharatpur, , Bikaner, Chittaurgarh, Churu, Dausa, Dhaulpur, Ganganagar, Hanumangarh, Jaipur, Jaisalmer, Jalore, Jhunjhunun, Jodhpur, Karauli, Nagaur, Pali, Pratapgarh, Sawai Madhopur, Sikar, Sirohi, Tonk, Udaipur recorded a decreasing trend. On the other hand, Baran, Barmer, Bhilwara Bundi, Dungarpur, Jhalawar, Kota, Rajsamand has an 
increasing trend. In case of post monsoon (min) groundwater levels, Alwar, Banswara, Bhilwara, Bikaner, Chittaurgarh, Churu, Dausa, Dhaulpur, Ganganagar, Hanumangarh, Jaipur, Jaisalmer, Jalore, Jhalawar, Jhunjhunun, Jodhpur, Nagaur, Pratapgarh, Rajsamand, Sawai Madhopur, Sikar, Sirohi show a decreasing trend. However, Ajmer, Baran, Barmer, Bharatpur, Bundi, Dungarpur, Karauli, Kota, Pali, Tonk and Udaipur recorded an increasing trend.

The groundwater levels in pre-monsoon (max) show a decreasing trend in the following districts of Rajasthan, viz. Alwar, Barmer, Bundi, Dausa, Jaipur, Jaisalmer, Jhunjhunun, Nagaur, Pratapgarh, Rajsamand, Sawai Madhopur, and Sikar. However, Ajmer, Banswara, Baran, Bharatpur, Bhilwara, Bikaner, Chittaurgarh, Churu, Dhaulpur, Dungarpur, Ganganagar, Hanumangarh, Jalore, Jhalawar, Jodhpur, Karauli, Kota, Pali, Sirohi, Tonk, and Udaipur recorded an increasing trend. On the other hand, post-monsoon $(\max )$ groundwater levels of Alwar, Banswara, Bharatpur, Dausa, Jaipur, Jaisalmer, Jhunjhunun, Sawai Madhopur, and Sikar show a decreasing trend, while Ajmer, Baran, Barmer, Bhilwara, Bikaner, Bundi, Chittaurgarh, Churu, Dhaulpur, Dungarpur, Ganganagar, Hanumangarh, Jalore, Jhalawar, Jodhpur, Karauli, Kota, Nagaur, Pali, Pratapgarh, Rajsamand, Sirohi, Tonk, and Udaipur show an increasing trend.

\section{CONCLUSIONS}

Mann Kendall's trend test was used to study the trend of groundwater levels in various network of observation wells districts of Rajasthan obtained from the Central Ground Water Board for both pre-monsoon and post-monsoon seasons. The The critical zones have been observed majorly in the wells of Bikaner district over the years followed by Jaisalmer, Jodhpur, Barmer, Ganganager, Hanumangarh, Jhunjhunun, Jaipur and Jalore. It can be proposed from the maps that the groundwater level had been at the most critical in 2010, i.e. $-119 \mathrm{~m} \mathrm{bgl}$ in pre-monsoon and $-112 \mathrm{~m} \mathrm{bgl}$ in post Monsoon. From 2010 to 2015 there has an increasing trend in groundwater level by $1.75 \mathrm{~m} \mathrm{bgl}$ in pre-monsoon and $1.69 \mathrm{~m} \mathrm{bgl}$ in post-monsoon. However, the critical zones are increasing spatially over the districts of Rajasthan due to population growth. Results from table 1 and 2 , it can be concluded that the minimum groundwater levels in the following districts viz. Alwar, Banswara, Bikaner, Chittaurgarh, Churu, Dausa, Dhaulpur,
Ganganagar, Hanumangarh, Jaipur, Jaisalmer, Jalore, Jhunjhunun, Jodhpur, Nagaur, Pratapgarh, Sawai Madhopur, Sikar, Sirohi show a decreasing trend in both pre-monsoon and post-seasons. In contrast, Alwar, Dausa, Jaipur, Jaisalmer, Jhunjhunun, Sawai Madhopur, and Sikar districts show a decreasing trend in maximum groundwater levels in both the seasons. Thus, Alwar, Dausa, Jaipur, Jaisalmer, Jhunjhunun, Sawai Madhopur and Sikar recorded declining trend in both maximum and minimum groundwater level and may need water conservation measures over the years.

\section{ACKNOWLEDGMENT}

The author is immensely grateful to Central Ground Water Board, Rajasthan for providing the groundwater level data.

\section{REFERENCES}

[1] Agarwal, E., Garg, R. D., \& Srivastav, S. K. Spatio-temporal trend analysis of groundwater level in Unnao district, Uttar Pradesh, India. International Journal of Creative Research Thoughts. 2017; 5(4), 1617-1626.

[2] Biswas, B., Jain, S. \& Rawat, S. Spatio-temporal analysis of groundwater levels and projection of future trend of Agra city, Uttar Pradesh, India. Arab J Geosci 11, $278 \quad$ (2018) https://doi.org/10.1007/s12517-018-3577-4

[3] Central Ground Water Board (CGWB), Ministry of Jal Shakti, Department of Water Resources River Development \& Ganga Rejuvenation, Central Ground Water Board. Government of India. Available http://59.179.19.250/GWL/GWL.html?UType=R2VuZXJhbA==? UName $=$

[4] Chinnasamy P, Maheshwari B, Prathapar S. Understanding Groundwater Storage Changes and Recharge in Rajasthan, India through Remote Sensing. Water. 2015; 7, 5547-5565; DOI: $10.3390 / \mathrm{w} 7105547,5548 .$.

[5] National Centre for Groundwater Research and Training: What is groundwater. Flinders University GPO Box 2100, ADELAIDE SA 5001, ABN: 65542596 200. Available at: http://www.groundwater.com.au/what-is-groundwater

[6] Narjary, B., Kumar, S., Kamra, S.K., Bundela, D.S., Sharma, D.K. Impact of rainfall variability on groundwater resources and opportunities of artificial recharge structure to reduce its exploitation in fresh groundwater zones of Haryana. Current Science. 2014; 107(8), 1305-1306

[7] Rede, H. N. A Study of Fluctuations in the Level of Underground Water in Jalna District, Maharashtra State, India. Geoscience Research. 2012; 3(2), 109.

[8] Yadav SS, Kumar L, Dey A. Ground Water Year Book 2014 - 2015, Rajasthan State. Government of India, Ministry of Water Resources, River Development \& Ganga Rejuvenation, Central Ground Water Board, Western Region, Jaipur. 2016. 